\title{
Teaching Process Mineralogy in Australia
}

Jeff Vaughan

Lawrie Davidson

Alex Nemchin

Stephen Quinton
Western Australian School of Mines, Curtin University of Technology, Perth, Western Australia, J.P.Vaughan@curtin.edu.au

Mineral Science and Extractive Metallurgy, Murdoch University, Perth, Western Australia, davidson@murdoch.edu.au

Western Australian School of Mines, Curtin University of Technology, Kalgoorlie, Western Australia, A.Nemchin@curtin.edu.au

Learning Support Network, Curtin University of Technology, Perth, Western Australia, S.Quinton@curtin.edu.au

\section{ABSTRACT}

The increasing complexity of ores processed today necessitates more detailed mineralogical characterisation than in the past. To ensure that metallurgists have the skills and knowledge required for this the Minerals Council of Australia is funding the preparation of curriculum materials for use in undergraduate and postgraduate courses in process mineralogy. Each course represents 75 contact hours of instruction and is being introduced progressively at universities in the Minerals Council's Australian network. Their modular format and appropriate use of WWW technologies mean the courses can be delivered to external students as well as those on campus. The undergraduate course adopts an active learning strategy with tasks written to "wrap around" established textbooks. Emphasis is on characterisation of ore minerals and mill products. All students will develop basic skills in reflected light microscopy using a virtual polarising microscope tutorial being prepared as a CD ROM. The postgraduate course develops understanding of sophisticated analytical techniques and their application: image analysis, advanced beam techniques for chemical analysis (including proton microprobe, dynamic SIMS, ICP-MS) and surface analysis. Case study material provides opportunities for students in both courses to study the application of mineralogy to problems in mineral processing and extractive metallurgy.

\section{INTRODUCTION - WHAT IS PROCESS MINERALOGY?}

Process mineralogy differs in practice from "geological" mineralogy in the questions it answers. After characterisation of mineral material in rocks the geological mineralogist is principally interested in questions of petrogenesis. How did these minerals form? What do they tell us about the origin of the rock in which they occur? The process mineralogist characterizes ore minerals and processing products with different questions in mind, such as: "How can these minerals be separated? In which minerals are the elements of value? Is there a mineralogical reason for low recovery? Are there surface coatings on particles that are interfering with flotation?" The scope of process mineralogy is nicely illustrated in the books of William Petruk (Petruk, 2000), Claudia Gasparrini (1993), Meurig Jones (1987) and the proceedings of meetings of the International Congress of Applied Mineralogy and the Commission on Applied Mineralogy of the International
Mineralogical Association (see, for example, Hagni, 1995).

Specialist process mineralogists are few in number and tend to work in technical laboratories of major mining houses, government research agencies (such as CANMET in Canada and Mintek in South Africa), a few universities (for example, at University of Missouri Rolla) and consultancies (for example, Amtel in London, Ontario). Many of the applied mineralogists who have shown the value of mineralogy in metallurgy are nearing the end of their professional careers. Regrettably, few mineralogists are being trained to take over their work.

The increasing complexity and lower grades of many ores being processed today put further demands on those responsible for the design and operation of metallurgical plants. This will be evident from the following description of problems encountered in the processing of refractory gold ores (ores that show low $\mathrm{Au}$ recovery after cyanide leaching) and their resolution through application of mineralogical studies. This illustration draws on case studies being prepared for the course and, ultimately, on the work of one us (Vaughan, 1997; Vaughan and Corrans, 1997; Vaughan and Kyin, 2002).

The problem with processing of gold ores is that often much of the gold is not present in the ores as the familiar native metal, but rather may be present as gold tellurides, antimony and bismuth compounds, or "invisible" gold (gold in solid solution within sulphide crystal lattices). Only native gold is easily soluble in alkaline cyanide solution (the usual way of extracting gold); for the other gold minerals more complicated pre-treatment is required (e.g. roasting or bacterial oxidation). It is sometimes very difficult for metallurgical test work to determine which of these types of gold are present in ores and the relative proportions of each type. Process mineralogy is essential in understanding these ores. The mineralogist may need to use reflected light microscopy, electron microprobe and/or secondary ion mass spectroscopy (SIMS) to fully determine gold deportment in a complex gold ore. In particular, SIMS is usually required to accurately measure invisible gold in sulphides. For example, if an ore contains fine-grained native gold particles locked in pyrite, then fine grinding possibly could be used to liberate the gold. However, if the gold is present as invisible gold in pyrite, then fine grinding is not an option and more expensive techniques must be used (Vaughan and Corrans, 1997). It makes good sense to correctly identify the deportment of gold prior to designing a plant. 


\section{AUSTRALIAN CURRICULUM DEVELOPMENT IN PROCESS MINERALOGY}

This paper reports on work-in-progress in the development of curriculum materials for undergraduate and postgraduate courses in process mineralogy. To add to the versatility of the materials we are preparing the postgraduate materials will be in a modular format suitable for presentation as professional development short-courses.

At the undergraduate level the new course is comparable in conceptual content to the mineralogy taught to geology majors but differs in its emphasis on mineral characterisation applied to mineral processing and extractive metallurgy rather than petrology. This course will not make mineralogists out of metallurgy students. It will, however, provide metallurgists with the knowledge and skills they need to understand their ores and enable them to more effectively interact with specialist mineralogists working in metallurgy. Our expectation is that this understanding will demonstrate to metallurgists the value of thorough characterisation of materials in processing streams as a way to solving problems in metallurgical operations rather than relying solely on metallurgical balances of process streams.

The postgraduate course develops understanding of sophisticated analytical techniques and their application in process mineralogy. These techniques include image analysis, advanced beam techniques for chemical analysis (including proton microprobe, dynamic SIMS, ICP-MS) and surface analysis. Case study material provides opportunities to study the application of these techniques to mineralogical problems in mineral processing and extractive metallurgy. Those who successfully complete the postgraduate course will have the basis for professional work in process mineralogy.

The process mineralogy curriculum development project is a component of an ambitious program initiated by the Minerals Council of Australia (MCA), the peak association representing the Australian minerals industry. In its report Back from the Brink (MCA, 1998) the MCA registered the industry's concern over the education and training of its future scientists and engineers. The MCA took action by establishing and funding (AUS \$15 million over five years) the Minerals Tertiary Education Council (MTEC) to work with Australian universities to ensure the sustainability of supply of mineral engineers and scientists. With student enrolments dropping and mining and metallurgy departments down-sizing (even closing) worldwide, the MTEC initiative was welcomed in the universities selected to participate in the program.

Curriculum development work funded by MTEC is underway in ore deposit and exploration geology, mining engineering, mineral processing and hydrometallurgy, as well as process mineralogy. The sharing of these high quality courses will strengthen Australian departments that continue to teach in minerals education, especially where staff shortages prevent a department from having expertise in all areas. The Australian minerals industry is underwriting its future in this way.

The Australian Commonwealth Government is supporting the MTEC initiative with the appointment of 15 lecturers (one in process mineralogy) under the Science Lectureship Initiative. These young academics are engaged in the development and delivery of the new courses. In this way there is a commitment to training the next generation of academic staff in key disciplines of national importance.

\section{DESIGN CRITERIA IN CURRICULUM DEVELOPMENT}

The project team has undertaken to provide curriculum materials that can serve a number of functions: undergraduate training, postgraduate training, professional development and as supplementary materials to support courses taught by others. The design criteria for the undergraduate course take account of the special requirements of the target group: a student body with diverse educational backgrounds; mature-age students as well as students straight from high-school; some students studying full time at a university campus, others part time at a mine site. Furthermore, the content of undergraduate courses has to be accessible as background knowledge to students enrolled in postgraduate courses or taking professional development short courses. Issues important to us in the design of the undergraduate materials are outlined below. Similar criteria are being considered for the postgraduate course materials being developed a little behind the schedule for the undergraduate materials.

i. Flexible delivery: The curriculum materials must be suitable for conventional delivery at a university, for delivery in the external mode to students on remote mine sites and for delivery to students on the campus of a partner university where studies may be coordinated by a non-specialist academic.

ii. Modular format: A modular format is being adopted to increase flexibility and versatility, especially in the use of the course materials as supplements to existing courses. It will also cater for "just-in-time" learning in which a student needs specific prior knowledge to study a more advanced topic but does not have the time to wade through a full course to get this background. Such students will be able to quickly "drill down" through linked materials to the information required. This provision recognises that many students, especially at postgraduate level, may have not taken courses in mineralogy in their first degree.

iii. Student-centred learning: Our prime objective is to facilitate independent, interactive student learning rather than supporting teacher-centred processes.

iv. Content: The study modules are being written to "wrap around" established texts in mineralogy (Klein, 2003; Nesse, 2001 and Hibbard 2002; Craig and Vaughan 1994). The study materials we are writing will encourage students to use the texts in a manner that encourages deeper understanding.

v. Appropriate use of the WWW: This is our biggest challenge because we are aware that dropping course content into html and up-loading it onto a web page - which is frequently done in the name of on-line teaching - is not effective for student learning. We are using the technological benefits of the WWW to facilitate communication and promote students' engagement with the materials rather than just as a means of delivery of content. Nevertheless, the course workbooks are being put into WWW-based format so that students have the option of working in the electronic medium and to allow 


\begin{tabular}{|c|c|c|}
\hline Module & Topics & Explanatory notes \\
\hline $\begin{array}{l}\text { 1. Basic concepts and processes in } \\
\text { geology. } \\
\text { (10 class hours) }\end{array}$ & $\begin{array}{l}\text { Planet Earth, minerals, igneous rocks, } \\
\text { weathering, sedimentary rocks, } \\
\text { metamorphic rocks, geological time, } \\
\text { dynamic earth, ore deposits. }\end{array}$ & $\begin{array}{l}\text { The module is presented at the level of } \\
\text { an introductory course in physical } \\
\text { geology; highlights ore-forming } \\
\text { processes. }\end{array}$ \\
\hline $\begin{array}{l}\text { 2. Basic concepts in mineralogy. } \\
\text { (8 class hours) }\end{array}$ & $\begin{array}{l}\text { Morphological crystallography, crystal } \\
\text { lattices, crystal chemistry, phase } \\
\text { chemistry of mineral system, structural } \\
\text { and chemical variation. }\end{array}$ & $\begin{array}{l}\text { Learning supported by kits of models } \\
\text { used in crystallography, crystal } \\
\text { chemistry and mineral structures. }\end{array}$ \\
\hline $\begin{array}{l}\text { 3. Systematic mineralogy. } \\
\text { (10 class hours) }\end{array}$ & $\begin{array}{l}\text { Native metals, sulphide and related } \\
\text { minerals, oxides, silicates (principles, } \\
\text { non-sheet silicates, sheet silicates, } \\
\text { especially clays), miscellaneous } \\
\text { (carbonates, etc). }\end{array}$ & $\begin{array}{l}\text { Emphasis placed on the metals, metal } \\
\text { sulphide and associated minerals, } \\
\text { oxide ore minerals and the common } \\
\text { gangue minerals - a different list from } \\
\text { the rock-forming mineralogy that } \\
\text { underpins petrology. }\end{array}$ \\
\hline $\begin{array}{l}\text { 4. Reflected light microscopy } \\
\text { (15 class hours) }\end{array}$ & $\begin{array}{l}\text { CD ROM tutorial provides simulation } \\
\text { of operation of reflected light } \\
\text { polarising microscope; diagnostic tests } \\
\text { used to identify principal ore minerals; } \\
\text { image collection. }\end{array}$ & $\begin{array}{l}\text { Including reflected light microscopy in } \\
\text { a first course in mineralogy may seem } \\
\text { surprising - especially when it likely } \\
\text { that students in remote places will } \\
\text { need to develop some capability in } \\
\text { mineral recognition using a reflected } \\
\text { light microscope. }\end{array}$ \\
\hline $\begin{array}{l}\text { 5. Mineralogy and textures of ore } \\
\text { deposits and processing products. } \\
\text { (10 class hours) }\end{array}$ & $\begin{array}{l}\text { All the important ore types are studied: } \\
\text { Magmatic (Ni, PGE, Ti, } \mathrm{Cr} \text {, diamonds), } \\
\text { VHMS (Cu, Zn), SEDEX (Pb, Zn); } \\
\text { hydrothermal (late magmatic, } \\
\text { mesothermal and epithermal } \mathrm{Au}) \text {; } \\
\text { laterites (Al, Ni); sedimentary (Fe, Mn, } \\
\text { HM sands); oxide/supergene ores; } \\
\text { mattes and slags. }\end{array}$ & $\begin{array}{l}\text { Although focus is on mineral } \\
\text { characterisation, association and } \\
\text { textures this module will develop } \\
\text { information profiles on principal ore } \\
\text { types including: ore deposit } \\
\text { characteristics; mineralisation; } \\
\text { ore-formation process; mining and } \\
\text { processing; special problems. }\end{array}$ \\
\hline $\begin{array}{l}\text { 6. Study of ore deposit suites and } \\
\text { processing products. } \\
\text { (14 class hours) }\end{array}$ & $\begin{array}{l}\text { Laboratory sessions using reflected } \\
\text { light microscope or CD ROM } \\
\text { simulation. }\end{array}$ & $\begin{array}{l}\text { Suites of materials selected to illustrate } \\
\text { what is studied in Module } 5 \text {. }\end{array}$ \\
\hline $\begin{array}{l}\text { 7. Mineralogical analysis. } \\
\text { ( } 8 \text { class hours })\end{array}$ & $\begin{array}{l}\text { X-ray diffraction, X-ray analysis, SEM, } \\
\text { electron microprobe. }\end{array}$ & $\begin{array}{l}\text { Worksheets will provide practice on } \\
\text { mineral identification and analysis. }\end{array}$ \\
\hline
\end{tabular}

Table 1. Content of modules in the undergraduate course.

better integration of images and text than can be $i$ provided in print at a reasonable cost. This is discussed further in a later section of this paper.

vi. Multiple resources: Learning in our process mineralogy courses is being supported by multiple resources available on students' desks, on their computers, or through links to relevant web sites. Printed and electronic study guides and workbooks, CD-ROMs, practical kits of minerals and models, a WebCT site, WWW links and on-line resources are to be used in the study package. Where the materials are to be used at other universities in the network there will be additional materials for the lecturer delivering the course, including PowerPoint slides and other materials to support lectures.

\section{APPLICATIONS OF WWW TECHNOLOGIES}

We are seeking to optimise the use of the WWW in students' learning. We are following Oliver et al (1998) and Brown et al (2001) in our consideration of the ways in which the WWW can foster learning through information access, encouraging interactive learning, facilitating communication and in the construction of new knowledge. i. Information access: Because there are excellent textbooks covering the concepts and principles of mineralogy and systematic descriptive mineralogy there is no need to consider using the WWW to deliver content. Furthermore, it has been reported by many workers in the field (Carr-Chellman and Duchastel, 2000; Brown et al 2001) that on-line textual content is rarely read on the screen and is usually downloaded to a printer. This has been our experience and we believe there is a strong case for providing such material in print form.

With many of our students likely to be located at isolated mine sites there are going to be data transmission problems - insufficient bandwidth, slow download speed and ISP costs. The needs of the most isolated student have to be considered first in the application of technology through the WWW.

Links to WWW mineral databases (such as www.webmineral.com) and annotated collections of images of ore minerals and their textures such as sponsored by the SME at www.smenet.org/ opaque-ore (see also Ixer and Dullard, 1998) are being incorporated.

ii. Interactive learning. The printed workbooks and tutorials-in-print are designed to be used independently of the WWW; they provide immediate feedback to questions posed in structured 


\begin{tabular}{|c|l|}
\hline Module & Topics \\
\hline $\begin{array}{c}\text { 1. Image analysis. } \\
\text { (10 class hours) }\end{array}$ & $\begin{array}{l}\text { Principles of image } \\
\text { analysis; SEM-based } \\
\text { systems; JKMLA and } \\
\text { QEM-Scan; optical-based } \\
\text { systems; applications to } \\
\text { mineral textures and } \\
\text { mineral liberation. }\end{array}$ \\
\hline $\begin{array}{l}\text { 2. Advanced beam } \\
\text { methods for mineral } \\
\text { analysis. } \\
\text { (9 class hours) }\end{array}$ & $\begin{array}{l}\text { Trace element analysis in } \\
\text { minerals using particle } \\
\text { beams; electron } \\
\text { microprobe; proton } \\
\text { microprobe; dynamic } \\
\text { SIMS; ICP-MS; valuable } \\
\text { and deleterious trace } \\
\text { elements in ores. }\end{array}$ \\
\hline $\begin{array}{l}\text { 3. Mineral surfaces. } \\
\text { (9 class hours) }\end{array}$ & $\begin{array}{l}\text { Theory of mineral } \\
\text { surfaces; sulphide, oxide } \\
\text { and metal surfaces; } \\
\text { adsorption of metals onto } \\
\text { mineral surfaces; } \\
\text { adsorption of organics } \\
\text { onto metal surfaces; } \\
\text { instrumental methods; } \\
\text { XPS; TOF-SIMS. }\end{array}$ \\
\hline $\begin{array}{l}\text { 4. Case studies in process } \\
\text { mineralogy. } \\
\text { (46 class hrs) }\end{array}$ & $\begin{array}{l}\text { Case studies covering a } \\
\text { wide range of } \\
\text { applications of process } \\
\text { mineralogy to } \\
\text { metallurgical problems. }\end{array}$ \\
\hline
\end{tabular}

Table 2. Content of modules in the postgraduate course.

in-text questions and the tutorials-in-print. A WebCT site is at the hub of our WWW strategy to engage students in interactive learning through communication and self-assessment tasks, including batches of multi-choice, short-answer and review questions. Answers to these questions are provided through the course tutor, allowing students' progress to be monitored and the provision of further instruction where required.

iii. Networked communication. We are making provision for student-student and teacher-student communication through a WebCT site in the form of

- Email study groups including those with membership bridging on-campus and remote students.

- A bulletin board for general discussion and provision of up-dated information.

- Presenting and up-dating the schedule for the course.

- Networked connections for small group work and joint problem solving.

- Feedback to individual students and, at a more generic level, to the whole class.

iv. Information construction: Through the WebCT site we will provide opportunities for collaboration in project work and to encourage students to share information on the more complex aspects of the course in ways that will improve learning. Group development of answers to review questions and problems based on case studies will be posted to a bulletin board. In this way we expect to stimulate student interaction and the development of summaries of concepts, principles and applications of process mineralogy that have more meaning to students that those that appear in texts.

\section{CURRICULUM AND CONTENT}

The undergraduate and postgraduate courses each represent 75 class contact hours, though it is not our intention that all teaching will be in a classroom setting. The content of the courses is listed in Tables 1 and 2 . While some parts of the courses are already being tested in our own courses we do not expect to have all the materials completed until the end of 2004. Initially the courses will be available only to member institutions of the MTEC consortium but in the longer term sections of the course materials will become available. Readers of this journal will be advised when materials have been placed on a website with general access.

The conceptual framework of the undergraduate course is similar to the first course in mineralogy taken by a geology major: crystallography and crystal chemistry, structural and chemical variation, phase chemistry and descriptive systematic mineralogy. Because our emphasis is on training students in mineralogical techniques to characterise ore minerals and metallurgical products rather than rock-forming minerals, we teach reflected light microscopy in place of transmitted light microscopy normally taught to support studies in petrology. Our course also introduces students to X-ray diffraction and analysis, SEM, EPMA and elementary aspects of image analysis. Advanced treatment of these techniques is presented in the postgraduate modules of our courses. Undergraduate students will have access to a file of case studies around which structured learning exercises are being written.

Even at undergraduate level we are striving to make students aware of the purpose of process mineralogy - to improve the efficiency of mineral processing and metallurgical operations. This emphasis shows up in our courses in a number of ways -

- Identification of mineral phases where often the minerals of interest are rare and occur in minor amounts in the ore (eg. tellurides in gold ores).

- Chemical compositions of minerals where often we are looking for very low levels of concentration of a valuable element (eg. "invisible" gold in pyrite).

- Quantities of minerals present and particle size as the first step in the design of comminution and liberation stages of processing.

- Mineral textures and intergrowths. How will these effect liberation?

\section{TEACHING REFLECTED LIGHT MICROSCOPY}

The most ambitious and technically demanding part of our work is the preparation of a learning module in reflected light microscopy. The issue here is that external students will not have access to a microscope. All students will develop basic skills in reflected light microscopy using a virtual microscope tutorial we have prepared and will issue as a CD ROM. Later in the course students will work on microscopes at intensive on-campus sessions to consolidate what they have learned on the virtual microscope. 


\begin{tabular}{|c|c|}
\hline Question & Answer \\
\hline $\begin{array}{l}\text { 1. There are two types of cation sites located between } \\
\text { chains. These are designated M1 and M } 2 \text { in Fig } 17 . \\
\text { Describe their locations relative to the silicate } \\
\text { chains. What is the coordination of each type of } \\
\text { site? }\end{array}$ & $\begin{array}{l}\text { M1 sites are located between the unshared apical } \mathrm{O} \\
\text { ions of Si-O tetrahedra. These sites are octahedral } \\
\text { coordinated } \mathrm{YO}_{6} \text { and are usually occupied by } \mathrm{Mg} \text { and } \\
\mathrm{Fe}^{2+} \text { ions (ionic radii } 0.07-0.08 \mathrm{~nm} \text { ). } \mathrm{M} 2 \text { sites are } \\
\text { bonded to shared O ions in the chain forming } \\
\text { coordination polyhedra of the type } \mathrm{XO}_{8} \text { (coordination } \\
\text { 8). Larger Ca and Na ions usually occupy these sites in } \\
\text { pyroxenes (ionic radii approximately } 0.112 \mathrm{~nm} \text { ). }\end{array}$ \\
\hline $\begin{array}{l}\text { 2. From your knowledge of the ionic radii of } \mathrm{O} \text { and } \\
\text { common elements you should be able to list } \\
\text { cations most likely to be located in M1 and M2 } \\
\text { sites. Try to do this now. }\end{array}$ & $\begin{array}{l}\text { M1 sites - Octahedral } \mathrm{YO}_{6} \text { site. Common cations are } \\
\mathrm{Mg}{ }^{2+}(0.072 \mathrm{~nm}), \mathrm{Fe}^{2+}(0.078 \mathrm{~nm}), \mathrm{Fe}^{3+}(0.065 \mathrm{~nm}), \mathrm{Ti}^{4+} \\
(0.061 \mathrm{~nm}) \text { and } \mathrm{Al}^{3+}(0.054 \mathrm{~nm}) . \\
\mathrm{M} 2 \text { sites - Cubic polyhedron, } \mathrm{XO}_{8} . \mathrm{Ca}^{2+}(0.112 \mathrm{~nm}), \\
\mathrm{Na}^{+}(0.118 \mathrm{~nm}) \text {. }\end{array}$ \\
\hline $\begin{array}{l}\text { 3. Do you remember our previous discussion about } \\
\text { the special role of } \mathrm{Al}^{3+} \text { ions in silicate minerals? In } \\
\text { which sites would expect to find } \mathrm{Al}^{3+} \text { in a pyroxene } \\
\text { that had been formed under high-pressure } \\
\text { conditions? Explain your answer. }\end{array}$ & $\begin{array}{l}\text { Because the } \mathrm{Al}^{3+} \text { has an ionic radius of } 0.039 \mathrm{~nm} \text { in } \\
\text { tetrahedral coordination and } 0.054 \text { in octahedral } \\
\text { coordination we could expect to find } \mathrm{Al}^{3+} \text { replacing } \\
\mathrm{Si}^{4+} \text { in tetrahedra } \mathrm{SiO}_{4} \text { tetrahedra and substituting for } \\
\text { octahedral ions in the } \mathrm{YO}_{6} \text { sites. Balancing } \\
\text { substitutions would be needed to maintain neutrality } \\
\text { in the structure. Jadeite, a high-pressure pyroxene that } \\
\text { occurs in mantle rocks, has the formula NaAlSi } \mathrm{O}_{6} \text {. In } \\
\text { jadeite } \mathrm{Al}^{3+} \text { ions occupy the } \mathrm{YO}_{6} \text { sites (smaller ions are } \\
\text { favoured in a site that has been subjected to pressure). }\end{array}$ \\
\hline
\end{tabular}

Table 3. Quick Response Questions (QRQs) included in the caption of a workbook diagram showing the structure of a pyroxene on an (001) projection. Layout in the workbook provides space for students to

All the standard diagnostic techniques we perform in routine reflected light microscopy have been simulated in our CD ROM tutorial. Images of minerals demonstrating diagnostic properties have been captured using a Leica DC 200 digital camera on an automated Leica DM-LP reflected light polarising microscope. Image capture has been obtained using proprietary software. Animation (principally rotation of the microscope stage) has been simulated by taking multiple images of a screen, one image per 10 degrees of rotation. These images were modified to reduce resolution slightly in order to reduce the size of the files in Corel Photo Paint. These multiple images have been converted to continuous rotation animation using Macromedia Director software.

Colour in minerals in reflected light is notoriously difficult to reproduce in digital photomicrographs. These problems are associated with some limitations of digital imaging in terms of the reproduction of colours on the different sides of the spectra (blue-red). This can result in the generation of a somewhat artificial colour when there are contrasts in mineral colours within the same polished surface; for example, in grey-yellow combinations. If the grey colour is adjusted perfectly then the colour of associated yellow minerals may appear a little brownish; if the colour of yellow minerals is set perfectly the adjusted grey colour has a tint of blue to it. This is specifically important for rotations, where the color is changing. The adjustment for one image may drift slightly when the stage is rotated. Patient manipulation of the colours of our digital images has enabled us to produced satisfactory colours of most minerals and allowed us to demonstrate subtle colours and reflectance, bireflectance, reflection pleochroism, and anisotropism. Physical properties such a scratch hardness and polishing relief, structural and morphological characteristics (crystal form, habit, cleavage, parting and twinning) and texture are easily demonstrated.
A collection of images of minerals and ores in reflected light is to be included on the CD ROM, along with a diagnostic key to aid metallurgists who are using reflected light microscopy to study ores and processing products.

We accept that this introduction to reflected light microscopy will not develop skills at the same level as those acquired through using a microscope. Our initial experience, however, has been that students have a better grasp of reflected light techniques through use of the simulation package than would have been gained through use of an atlas of still photomicrographs. We anticipate that students who use the microscopy simulation tutorial will make rapid progress when they eventually have access to a microscope. Furthermore, they will have sufficient knowledge to sit with mineralogists undertaking reflected light microscopy and to read their reports with deeper understanding. Those metallurgists who get the opportunity to work with a microscope will have had a flying start from their studies through the simulation package.

\section{INTERACTIVE LEARNING}

The undergraduate workbook is designed to develop a dialogue with students and to allow them to take a more independent approach to their learning. The structure of the workbook provides for each module and topic -

i. A list of learning objectives - what students are expected to know or skills to have been acquired on the successful completion of their study of a particular topic.

ii. Relevant principles and concepts presented as brief statements with information links to textbooks, tutorials in the workbook, or WWW sources, as appropriate.

iii. Tutorials-in-print (TIPs) to engage students in structured exercises to develop understanding of 


\begin{tabular}{|c|c|}
\hline Question & Answer \\
\hline $\begin{array}{l}\text { Compare the diagram of the chlorite structure with } \\
\text { the diagrams for talc and muscovite. List five points of } \\
\text { similarity or difference. }\end{array}$ & $\begin{array}{l}\text { iI. Talc and chlorite each have a plane of } \mathrm{Mg}^{2+} \text { ions in } \\
\text { the O-sheet; muscovite has } \mathrm{Al}^{3+} \text { ions; chlorite may } \\
\text { have some } \mathrm{Al}^{3+}=\mathrm{Mg}^{2+} \text { substitution in the O-sheet. } \\
\text { ii. Muscovite and chlorite have } \mathrm{Al}^{3+}=\mathrm{Si}^{4+} \\
\text { substitution in the T-sheet. } \\
\text { iii. Chlorite has a } \mathrm{Mg} \text {-OH interlayer (a "brucite sheet" } \\
\text { analogous to the "gibbsite" sheet in kaolinite) whereas } \\
\text { muscovite has } \mathrm{K}^{+} \text {ions in the interlayer position; } \mathrm{Al}^{3+}= \\
\mathrm{Mg}^{2+} \text { substitution occurs in the interlayer. } \\
\text { iv. Talc has no interlayer ions. } \\
\text { v. The thick interlayer (I-sheet) in chlorite increases } \\
\text { the repeat unit distance to } 1.4 \mathrm{~nm} \text { ( } 0.9 \mathrm{~nm} \text { in talc } \\
\text { and } 1.0 \mathrm{~nm} \text { in muscovite). }\end{array}$ \\
\hline
\end{tabular}

Table 4. Quick Response Question (QRQ) included in the caption of a workbook diagram showing the layered structure of chlorite. Layout in the workbook provides space for students to write answers.

concepts. These can be exercises using crystal and structural models, calculations based on phase diagrams, evaluation of x-ray diffraction data, mineral identification and the interpretation of reflected light photomicrographs or SEM images. Students often find that diagrams, tables and other information presented in the tutorial exercises are incomplete. This is a deliberate strategy on our part. By having to seek out the missing information from texts and other sources students gain a sense of ownership of the content of the workbook. Completed diagrams and tables are presented elsewhere in the workbook.

iv. Questions inserted into the text of the workbook have been designated as ITQs (in-text questions), and QRQs (quick response questions). Answering these questions whenever they come up in the workbook engages students in active learning. QRQs are printed in a distinctive font to make them stand out in the text of the workbook. Space is provided to allow students to write an answer to the question directly in workbook. In this way students personalise their study materials in a manner that is more effective in learning than a slash with a highlight pen! Our experience has been that students have a greater sense of ownership of the materials because they have invested time in their construction.

v. In-text questions (ITQs) are more substantial than QRQs and may involve a calculation or more lengthy activities than encountered in the QRQ's. Answer to ITQs are presented at the back of the workbook.

As an example of our approach to encourage active learning we present here questions that appear in the caption to a diagram of a (001) projection of the pyroxene structure (see Table 3). Rather than telling students the principal features of the pyroxene structure we ask questions that require them to build up their own understanding. These take the form of $\mathrm{QRQ}$ (quick response questions). We want students to stop and think about questions and write brief answers on the workbook page before reading on to obtain the information. A second example on this approach to active learning is seen in the caption to a diagram of the layered structure of chlorite (Table 4 ).

\section{CASE STUDIES}

Case studies are a special feature of materials we are preparing for the MTEC courses. While these are primarily written for postgraduate students they will have application in the undergraduate course. The case studies document the successful application of process mineralogy to the solution of problems in mineral processing and extractive metallurgy. Profiles we are preparing on the principle ore types will include information on mineral-related processing problems inherent in each ore type. For instance, metallurgists processing ores from serpentinised komatiite-hosted $\mathrm{Ni}$ sulphide ores will be alerted to problems arising from talc adhering to sulphide concentrates and becoming entrained in the feed to the smelter. The higher $\mathrm{Mg}$ content of the charge raises the melting point of the slag resulting in the entrapment (and loss) of $\mathrm{Ni}$ matte droplets and the need to prevent crusts forming by running the furnace at higher temperatures than for an Mg-free system.

Each case study presents technical information on ores or processing products, mineralogical and analytical data, images, discussion of problems encountered and the outcomes of mineralogical studies, and references to the relevant literature. Some case studies are being written in the form of problems to be solved by students working as "consultants" in teams. Students will be able to access relevant information from databases on the course WebCT hub. Reports written by students will be available on a WebCT bulletin board for discussion and comparison with the actual outcome of the original study.

Some of the topics being prepared as case studies are -

- Refractory and preg-robbing gold ores

- Sulphide Ni ores including supergene mineralisation.

- PGE's in sulphides

- Base metal (Cu-Pb-Zn) ores

- Reagent consumption in gold processing (Cu, pyrrhotite).

- Recovery of Ag from base metal sulphide ores.

- Heavy mineral sands (including natural and synthetic $\mathrm{Ti}$ )

- Uranium ores and radioactive waste disposal 
- Clays and environmental mineralogy

- Light metal processing - $\mathrm{Al}, \mathrm{Si}, \mathrm{Mg}$

- Pegmatite minerals

- $\mathrm{Ni}$ and $\mathrm{Cu}$ mattes and slags

- Diamonds and indicator minerals

- Refractory materials

- Phosphorous in iron ores.

\section{CURRICULUM MATERIALS BEING DEVELOPED}

The complete teaching and learning package for the undergraduate course includes the following materials -

- Printed course workbook divided into blocks of topics that present: lists of learning objectives; statements of principles and concepts relevant to the topic; tutorials-in-print; self-assessment questions and answers. The layout of the workbook provides a framework to guide students through a sequence of tasks that represent a reasonable workload for a study session.

- CD ROM and on-line versions of the course workbook. This is done to facilitate links between modules, access between the undergraduate and postgraduate courses, and following WWW links. A site map and consistent screen formats will help students as they navigate through the materials.

- CD-ROM tutorial on reflected light optical techniques and their application.

- CD ROM image file.

- WebCT site as the hub for WWW activities.

- PowerPoint lecture notes to be available to academics at other MTEC institutions to up grade their presentation in process mineralogy.

\section{CONCLUSIONS}

The initiative of the Minerals Council of Australia in funding the development of undergraduate and postgraduate courses in process mineralogy will ensure that metallurgists educated at Australian universities will have a solid understanding of mineralogy. Those who study process mineralogy at postgraduate level whether as students formally enrolled for a higher degree or as professional metallurgists engaging in professional development - will acquire knowledge and skills that will prepare them for professional work in mineralogy. Although the focus for the curriculum development is on process mineralogy and metallurgy, the new materials will have wider application in the teaching of mineralogy. This applies especially to the structured workbooks addressing the fundamental concepts and principles of mineralogy, the CD ROM instructional tutorial on reflected light microscopy using our virtual polarising microscope, and the collection of case studies on the application of mineralogy to processing problems. General access to these materials will become available progressively after the completion of the MCA project.

\section{ACKNOWLEDGMENTS}

Without the initiative and financial commitment of the Australian Minerals Tertiary Education Council this curriculum development work in process mineralogy would not be undertaken. The funding provided by the Australian Commonwealth Government towards a lectureship at Curtin University under the Science Lectureships Initiative is gratefully acknowledged.

\section{REFERENCES}

Brown, A., 1997, Designing for learning: What are the essential features of an effective on-line course?, Australian Journal of Educational Technology, v.13, p.115-126.

Brown, A., Drinkwater, D., Schroder, A., and Kelly, G., 2001, Encouraging active learning with more interactive WWW designs: Unpublished paper presented at MTEC Workshop - Exploring the possibilities for distance learning, Pokolbin, NSW, Minerals Council of Australia, $12 \mathrm{p}$.

Carr-Chellman, A., and Duchastel, P., 2000, The ideal on-line course, British Journal of Educational Technology, v. 31, p. 229-241.

Craig, J. R., and Vaughan, D.J., 1994, Ore microscopy and ore petrography, New York, John Wiley, 434 p.

Gasparrini, C., 1993, Gold and other precious metals, Berlin, Spinger-Verlag, $335 \mathrm{p}$.

Hagni, R.D., editor, 1995, Process Mineralogy XIII, Warrendale, Metallurgical Society, $377 \mathrm{p}$.

Hibbard, M.J., 2002, Mineralogy, New York, McGraw-Hill, $562 \mathrm{p}$.

Ixer, R.A., and Duller, P.R., 1998, Virtual atlas of opaque and ore minerals in their associations, CD ROM privately produced by authors, Available at: http:/ / www.smenet.org/opaque-ore

Jones, M.P. 1987, Applied Mineralogy, London, Graham and Trotman, $259 \mathrm{p}$.

Klein, C., 2002, Mineral Science, New York, John Wiley, $641 \mathrm{p}$.

Minerals Council of Australia, 1998, Back from the Brink - Reshaping minerals tertiary education in Australia, Canberra, Minerals Council of Australia, 59 p. Available at http:/ / www.minerals.org.au.

Nesse, W.D., 2000, Introduction to Mineralogy, Oxford, Oxford University Press, $442 \mathrm{p}$.

Oliver, R., Omari, A., and Ring, J., 1998, Connecting and engaging learners with the WWW, In Black, B., and Stanley, N., editors, Teaching and Learning Forum Proceedings, Nedlands, The University of Western Australia, p. 237-241.

Petruk, W., 2000, Applied mineralogy in the mining industry, Amsterdam, Elsevier, 268 p.

Vaughan, J. P., 1997, Process mineralogy of refractory gold ores in theYilgarn Craton of Western Australia. In Kalgoorlie '97, An International Conference on Crustal Evolution, Metallogeny and Exploration of the Yilgarn Craton - An Update, Australian Geological Survey Organization, Record 1997/41, p. $177-181$.

Vaughan, J. P., and Corrans, I. J., 1997, Estimation of submicroscopic gold inores by SIMS and ultrafine milling: a comparative investigation, in SIMS XI, editors, Gillen, G., Lareau, R., Bennett, J., and Stevie. F, Eleventh International Conference on Secondary Ion Mass Spectrometry, Florida, New York, John Wiley and Sons, p. $811-814$.

Vaughan, J. P., and Kyin, A., 2002, Classification of refractory gold ores in Archean greenstones, Western Australia, International Mineralogical Association, 18th General Meeting, Edinburgh, September, Abstracts, p. 267. 